\title{
Chemical Compositions, Antioxidant Activities, and Mineral Matter Contents of Achillea collina Becker ex Rchb from the Flora of Bulgaria
}

\author{
Hülya DOĞAN ${ }^{*}$, Tansu USKUTOĞLU ${ }^{2}$, Hafize FIDAN ${ }^{3}$, Stanko STANKOV³, Hatice BAŞ4, Belgin COŞGE \\ ŞENKAL ${ }^{2}$, Albena STOYANOVA ${ }^{5}$, Nadezhda PETKOVA ${ }^{6}$, Ivayla DINCHEVA7 , Güngör YILMAZ²
${ }^{1}$ Yozgat Vocational School, Seed Science Program, Yozgat Bozok University, Yozgat, Turkey ${ }^{3}$ Department of Nutrition and Tourism, Faculty of Economics, University of Food Technologies, Plovdiv, Bulgaria ${ }^{4}$ Department of Biology, Faculty of Science and Literature, Yozgat Bozok University, Yozgat, Turkey \\ ${ }^{2}$ Departmant of Field Crops, Faculty of Agriculture, Yozgat Bozok University, Yozgat, Turkey \\ ${ }^{5}$ Technological Faculty, Technology of Tobacco, Sugar, Vegetable and Essential oils, University of Food Technologies, Plovdiv, Bulgaria \\ ${ }^{6}$ University of Food Technologies, Technological Faculty, Department of Organic Chemistry and Inorganic Chemistry, Plovdiv, Bulgaria \\ ${ }^{7}$ AgroBioInstitute, Sofia, Bulgaria \\ ORCID ID: Hülya DOĞAN: https:/ / orcid.org/0000-0003-1970-4123; Tansu USKUTOĞLU: https:/ / orcid.org/0000-0001-6631-1723; Hafize \\ FIDAN: https:/ / orcid.org/0000-0002-3373-5949; Stanko STANKOV: https://orcid.org/0000-0003-2332-1782; Hatice BAŞ: \\ https://orcid.org/0000-0001-8296-0360; Belgin COŞGE ŞENKAL: https://orcid.org/0000-0001-7330-8098; Albena STOYANOVA: \\ https://orcid.org/0000-0001-7140-7826; Nadezhda PETKOVA: https://orcid.org/0000-0002-5870-9157; Ivayla DINCHEVA: \\ https:// orcid.org/0000-0003-0276-4170; Güngör YILMAZ: https:// orcid.org/0000-0003-0070-5484
}

\begin{tabular}{llll}
\hline Received: 14.08 .2021 & Accepted: 01.10.2021 & Published online: 18.10 .2021 & Issue published: 31.12 .2021 \\
\hline
\end{tabular}

\begin{abstract}
Medicinal plants are mostly used in pharmaceutical, nutrition, and nutraceutical fields. Achillea spp. is widely used as nutraceuticals and food. In this study, chemical composition of essential oils, mineral composition, and antioxidant activities of different parts of A. collina were investigated. Flavonoids and polyphenols were detected using total flavonoid and polyphenolic contents assays. The Antioxidant activities were identified using 1,1-Diphenyl-2-picrylhydrazyl (DPPH), Ferric Reducing Antioxidant Power (FRAP), and Trolox Equivalent Antioxidant Capacity (TEAC) assays. The essential oil chemical compositions were determined by Gas Chromatography-Mass Spectrometry (GC-MS) analysis. According to the results, the most active plant part was A. collina leaves with a value of $\mathrm{IC}_{50}=62.32 \pm 1.53 \mu \mathrm{g} / \mathrm{mL}$. The highest total phenolic and flavonoid contents $(171.66 \pm 0.47 \mathrm{mg} \mathrm{GAE} / \mathrm{g}$ and $8.50 \pm 0.43 \mathrm{mg} \mathrm{QE} / \mathrm{g})$ were found in leaf parts. The essential oil was only obtained from the flower part of the plant. Besides, the major components found in A. collina were 1,8-cineole, camphor, $\beta$-linalool, $\gamma$ terpinene, $\gamma$-terpineol, a-pinene, epi-cyclocolorenone, epi-cyclocolorenone, and $p$-cymene. The results revealed that leaf samples of A. collina obtained from Bulgarian flora had higher antioxidant effect. The highest macro and microelement contents were Potassium $(\mathrm{K})>$ Calcium $(\mathrm{Ca})>$ Manganese $(\mathrm{Mn})>$ Phosphor $(\mathrm{P})>$ Magnesium $(\mathrm{Mg})>$ Sodium $(\mathrm{Na})>\mathrm{Copper}(\mathrm{Cu})>\operatorname{Iron}(\mathrm{Fe})>$ Boron (B), respectively.
\end{abstract}

Keywords: Asteraceae, essential oils, antioxidant activity, mineral matter.

\section{Bulgaristan Florasında Yetişen Achillea collina Becker ex Rchb'ın Kimyasal Bileşeni, Antioksidan Özellikleri ve Mineral Madde İçeriği}

\begin{abstract}
Öz: Tıbbî bitkiler daha çok ilaç, gıda ve nutrasötik alanlarda kullanılmaktadır. Achillea spp. nutrasötikler veya gıdalar halinde yaygın olarak kullanılan bir bitkidir. Bu çalışmada A. collina'nın farklı kısımları kullanılarak uçucu yağ bileşenleri, mineral maddeleri, toplam flavonid, toplam fenolik içeriği ve antioksidan aktivitesi belirlenmiştir. Antioksidan aktivitesinin belirlenmesinde; 1,1-Difenil-2-pikrilhidrazil (DPPH), Ferrik İndirgeyici Antioksidan Gücü (FRAP) ve Trolox Eşdeğer Antioksidan Kapasitesi (TEAC) analizleri yapılmıştır. Uçucu yağın kimyasal kompozisyonu Gaz Kromatografisi-Kütle Spektrometrisi (GC-MS) analizi ile belirlenmiştir. Sonuçlara göre A. collina' nın bitki kısımlarından en yüksek antioksidan aktivitesi $\mathrm{IC}_{50}=62.32 \pm 1.53 \mu \mathrm{g} / \mathrm{mL}$ değeri ile yapraklarından elde edilmiştir. En yüksek toplam fenolik ve flavonoid içerikleri (171.66 $\pm 0.47 \mathrm{mg} \mathrm{GAE} / \mathrm{g}$ ve $8.50 \pm 0.43 \mathrm{mg} \mathrm{QE} / \mathrm{g}$ ) yaprak kısımlarında tespit edilmiştir. Uçucu yağ sadece bitkinin çiçek kismindan elde edilmiştir. A. collina'da bulunan ana bileşenler 1,8-sineole, kafur, $\beta$-linalool, $\gamma$-terpinen, $\gamma$-terpineol, $a$-pinen, epi-siklokolorenon, epi-siklokolorenon ve $p$-simen olarak tespit edilmiştir. Sonuçlar, Bulgaristan florasından elde edilen $A$. collina' nun yaprak örneklerinin daha yüksek antioksidan etkiye sahip olduğunu ortaya koymuştur. En yüksek makro ve mikro element içerikleri sırasıyla Potasyum $(\mathrm{K})>\operatorname{Kalsiyum}(\mathrm{Ca})>$ Mangan $(\mathrm{Mn})>$ Fosfor $(\mathrm{P})>$ Magnezyum $(\mathrm{Mg})>$ Sodyum $(\mathrm{Na})>$ Bakır $(\mathrm{Cu})>$ Demir $(\mathrm{Fe})>$ Bor $(\mathrm{B})$ olarak belirlenmiştir.
\end{abstract}

Anahtar kelimeler: Asteraceae, uçucu yağlar, antioksidan aktivite, mineral madde.

\section{Introduction}

The development of modern perceptions about the role of herbal medicine and a healthy lifestyle leads to the rational use of medicinal plants both in Bulgaria and in all developed countries. New health tendencies require the development of national strategies for preserving their diversity and sustainable use. In Bulgaria, the management plan emphasizes its goals on the image and quality management of the Bulgarian flora. The competition on the herbal market in the international plan is high, which requires the rational use of the wide varieties and introduced samples, to create sustainable 
programs for various maintenance and to build zoning points in places suitable for growing medicinal plants (Dzhabarova \& Peneva, 2017).

Achillea spp., known as yarrow, is widely used as a medicinal and aromatic plants in the world. There are about 110-140 species in the genus Achillea (Asteraceae). Most of them are located in Europe, Asia, and North Africa (Konemann, 1999; Oberprieler et al., 2007). Medicinal plants of A. millefolium L. group in Bulgarian wild flora are widely used in both traditional medicine and pharmaceutical, cosmetics, and nutritive industries (Edreva et al., 2017).

Achillea species in European folk medicine are widely used in the treatment of inflammatory diseases. Achillea ssp. contains flavonoids that increase saliva and stomach acid helping to improve digestion. The flowers are often used to treat hay fever and various allergic mucus problems. The dark blue essential oil is obtained from its flowers and often used as an anti-inflammatory or chest rub for colds and influenza. The leaves encourage clotting so it can be used fresh for nosebleeds (Choudhary et al., 2007; Lakshmi et al., 2011; Ali et al., 2017; Chávez-Silva et al., 2018).

Concerning the bioactivity of Achillea millefolium, recent studies reported antioxidant and antimicrobial activities, antiphlogistic, hepatoprotective, gastrointestinal, antispasmodic, diuretic, urinary antiseptic, and calcium antagonist activities of its polar extracts (Stojanović et al., 2005; Georgiev \& Stoyanova, 2006; Yaeesh et al., 2006; Ali et al., 2017).

Most of the components obtained from Achillea species are highly bioactive (Mockute \& Judzentiene, 2010). A. millefolium is considered as one of the most important species that is represented with the species of $A$. rosea alba Ehrend., A. asplenifolia Vent., A. setacea Walds. \& Kit., A. collina Becker ex Rchb, A. pratensis Saukel \& Länger, A. millefolium L., and Achillea pannonica Scheele (Bocevska \& Sovova, 2007; Rehus \& Neugebauerova, 2011). A. collina is a common species for the Central Europe and rich in monoterpenes and sesquiterpenes and more than 120 chemical compounds have been identified (Nemeth, 2005). Various assays have been used in order to evaluate the antioxidant capacity of herbal products and foods (Somogyi et al., 2007; Dzhabarova \& Peneva, 2017).

The presence of a wide variety of medicinal plant species and their preservation as an element of traditional homeopathic practices for the prevention and treatment of the local population are the subject of various analyses. Social change, globalization, and the industrialization of agriculture, including the production of aqueous extracts of herbs, increase the need for in-depth knowledge of the composition and possible methods of technological preparation. The increased demand for some valuable medicinal plant species with not widespread distribution leads to targeted cultivation. The incentives offered by several Euro-projects for small and medium-sized businesses to reduce unemployment have also significantly increased the interest of young Bulgarian farmers in herbal production and, through it, the development of alternative forms of tourism as part of industries of national importance (Vitkova et al., 2005; Trendafilova et al., 2006). On the other hand, natural resources particularly the availability of medicinal plant species popularize the regions by creating adequate marketing tools for synergy between natural resources and alternative forms of tourism.

The aim of the present study was to investigate the chemical properties, mineral compositions, and antioxidant capacities of essential oil components obtained by using different parts (leaf and flower) of Achillea collina from Bulgaria.

\section{Material and Methods}

\subsection{Material}

The plants were collected in October 2016 from the region of Sliven town $\left(42.865844^{\circ} \mathrm{N} 26.133691^{\circ} \mathrm{E}\right.$, Bozhevtsi). The plant species was identified by Paisii Hilendarski University of Plovdiv, Faculty of Biology, the Department of Botany and Methods of Biology Teaching. The identification of the species is based on morphological features. The raw material has been submitted to the herbarium of the Bulgarian Academy of Sciences; however, we still have not received the required number. The plants are dried at room temperature $\left(25^{\circ} \mathrm{C}\right)$, in the shade away from direct sunlight, until equilibrium humidity is reached $(8-10 \%)$. The dried raw material is stored in closed paper two-layer bags, in cabinets in the dark and away from heat. Before processing, the raw material is cut to size $1 \mathrm{~cm}$.

\subsection{Extraction}

The plant (leaf and flower) sample $(4 \mathrm{~g})$ were mixed by methanol $(40 \mathrm{~mL})(1 / 10 \mathrm{w} / \mathrm{v})$. The prepared samples were incubated for 24 hours at $40^{\circ} \mathrm{C}$ in an oven (Electo-mag $\mathrm{M}$ $5040 \mathrm{P}$ ). Then, it was filtered into balloon flasks (Whatman No 1 filter paper). The methanol in the samples was removed with the help of a rotary evaporator (Heating Bath B-491, BUCHI). The balloon bottles, which were blown up, were kept in the oven for 24 hours and completely dried. The extracts were taken into falcon tubes and closed with parafilm and stored at $+4^{\circ} \mathrm{C}$ to be used in the analysis.

\subsection{Chemical composition}

The plants moisture was determined by drying up to the constant weight at $105^{\circ} \mathrm{C}$ and the results from the chemical analyses were given on a dry weight (DW) basis. The ash content was determined according to AOAC (2005), by mineralization of the samples at $550^{\circ} \mathrm{C}$ for 5 hours.

\subsubsection{Isolation of essential oil}

The essential oil was isolated by hydrodistillation (50 $\mathrm{g}$ of flowers) (the ratio of flowers: water $=1: 10$ ) for 3 hours using a Clevenger apparatus (Balinova \& Diakov, 1974). The essential oil was stored in dark vials at $4^{\circ} \mathrm{C}$ until analysis. Essential oil could not be obtained from leaf samples.

\subsubsection{Chromatography-Mass Spectrometry (GC-MS) analysis}

The compounds of the essential oil were detected with gas chromatography (GC) (Agilent 7890A), temperature; $35^{\circ} \mathrm{C} / 3 \mathrm{~min}, 5^{\circ} \mathrm{C} / \mathrm{min}$ to $250^{\circ} \mathrm{C}(3 \mathrm{~min})$, total 49 minutes, HP-5 column MS (30 m x $250 \mu \mathrm{m} \times 0.25 \mu \mathrm{m}), 1 \mathrm{~mL} / \mathrm{min}$ constant speed, 30:1 split ratio. Helium was used as carrier 
gas. The GC-MS analysis (Agilent 5975C mass spectrometer) was used the same column and temperature as in the GC analysis. The essential oil components were identified by comparing their relative retention time and library data (NIST 08 database) (Adams, 2007). And then, compounds retention indices (Kovat's) were listed.

\subsubsection{Protein content}

The total protein content (the samples $1 \mathrm{~g}$ each) was determined by the method of AOAC (2016) with a UDK 152 Kjeldahl System.

\subsubsection{Cellulose content}

The cellulose content (crude fiber) in the leaf and flower samples was determined by the method of Brendel et al. (2000).

\subsubsection{Chlorophylls and carotenoid contents}

For evaluation of chlorophyll a, chlorophyll b, and the total carotenoids content, $0.5 \mathrm{~g}$ of plant samples were homogenized with $10 \mathrm{~mL}$ extract ( $80 \%$ alkaline acetone) and stored in the dark at $25^{\circ} \mathrm{C}$ for 24 hours. Then centrifuged at $1500 \mathrm{~g}$ for 10 minutes. Absorbance was measured at $470 \mathrm{~nm}, 645 \mathrm{~nm}$ and $663 \mathrm{~nm}$. Then the results were calculated according to the method proposed by Corte Real et al. (2017):

$$
\begin{aligned}
& \text { Chlorophyll a }(\mathrm{mg} / \mathrm{L})=9.784^{*} \mathrm{~A} 663-0.990 * \mathrm{~A} 645 \text { (1) } \\
& \text { Chlorophyll b }(\mathrm{mg} / \mathrm{L})=21.426^{*} \mathrm{~A} 645-4.650 * \mathrm{~A} 663(2)
\end{aligned}
$$

Total carotenoids content $(\mathrm{mg} / \mathrm{L})=4.695^{*} \mathrm{~A} 470-0.268^{*}(\mathrm{chl} \mathrm{a}+\mathrm{chl} \mathrm{b})(3)$

\subsubsection{Nutrient contents}

Flower plant parts were dried and $0.5 \mathrm{~g}$ was weighed. Then, each sample was put into a porcelain crucible. All samples were burned until gray ash $\left(550^{\circ} \mathrm{C}\right)$. After burning the $0.5 \mathrm{~g}$ weighed samples, the ashes were dissolved in 4 $\mathrm{mL} 0.1 \mathrm{~N} \mathrm{HCl}$ and filtered (Whatman No. 1), and completed with distilled water $(10 \mathrm{~mL})$ (Kaçar \& İnal, 2010). Mineral and heavy metal contents were determined by Yozgat Bozok University, Science and Technology Application and Research Center using iCAP-Qc ICP-MS spectrometer (Thermo Scientific). The analysis was not performed for leaf samples due to the insufficient amount of leaf sample.

\subsubsection{Total phenol contents assay}

Folin-Ciocalteu Reagent (FCR) method was used to determine the total phenolic content of the $40 \mathrm{~mL}$ of methanol extracts (Singleton et al., 1999). For the study, 100 $\mathrm{mL}$ of sodium carbonate solution was prepared. To prepare the saturated sodium carbonate solution, $20 \mathrm{~g}$ of sodium carbonate was first weighed and $80 \mathrm{~mL}$ of hot distilled water was added to it. The lid of this solution was covered by boiling and dissolved thoroughly. After dissolution, the temperature of the solution was cooled down to room temperature. Approximately $7 \mathrm{~g}$ of sodium carbonate was added on top and the solution was saturated. The resulting solution was left in the dark for 24 h. Samples were prepared for later analysis. First, $2.4 \mathrm{~mL}$ of pure water was placed in glass tubes and $40 \mu \mathrm{L}$ of extract was added. $40 \mu \mathrm{L}$ methanol was added to the prepared control groups instead of extracts. Then, $200 \mu \mathrm{L}$ of folin and $600 \mu \mathrm{L}$ of saturated sodium carbonate were added to the samples. In the next step, $760 \mu \mathrm{L}$ of distilled water was added and vortexed for complete mixing of the added chemicals. The prepared samples were incubated at room temperature for $2 \mathrm{~h}$ and absorbance measurement was performed at $765 \mathrm{~nm}$. Gallic acid was used for standard phenolic substance control. The values obtained are expressed as gallic acid conjugate. Spectrophotometric measurements to determine the total phenolic content PerkinElmer Lambda 25 UV/VIS made in spectrophotometer device.

\subsubsection{Total flavonoids content assay}

The total flavonoid compound amounts of the $40 \mathrm{~mL}$ methanol extracts were determined by optimizing the aluminum chloride colorimetric method of Biju et al. (2014). $1 \mathrm{mg} / \mathrm{mL}$ extract was prepared. Plant extract $50 \mu \mathrm{L}$ was mixed with methanol $950 \mu \mathrm{L}$. Then, $4 \mathrm{ml}$ of distilled water was added and mixed. $0.3 \mathrm{~mL}$ sodium nitrate $\mathrm{NaNO} 2(5 \%)$ was added and incubated for $5 \mathrm{~min}$. Then, 0.3 $\mathrm{mL}$ of aluminum chloride $(10 \%)$ was added and incubated for $6 \mathrm{~min}$. After incubation, $2 \mathrm{~mL}$ of $1 \mathrm{~mol} / \mathrm{L}$ sodium hydroxide was added. To the resulting solution, $2.4 \mathrm{~mL}$ of distilled water was added and completed to $10 \mathrm{~mL}$, then the solution was incubated for $15 \mathrm{~min}$. Later, absorbance at $510 \mathrm{~nm}$ was evaluated. As result of quercetin equivalents (QE)/g of extract was calculated.

\subsubsection{DPPH (1,1-diphenyl-2- picrilhydrazyl) free radical assay}

The free radical activities of the extracts were determined using DPPH (1,1-diphenyl-2- picrilhydrazyl) free radical, a known, and commonly used radical (Gezer et al., 2006). Firstly, the amount of extract that defines a certain amount of DPPH radical has been determined and a comparison has been made between these samples. $16 \mathrm{mg}$ DPPH radical solution was prepared in $100 \mathrm{~mL}$ methanol. The DPPH solution was used in the analysis and was prepared as $0.1 \mu \mathrm{M}$. By setting $517 \mathrm{~nm}$ in the spectrophotometer, $\mathrm{DPPH}$ reading was done and dilution was made with methanol until the absorbance value was $1.000 .1 \mathrm{mg} / \mathrm{mL}$ extract solution was prepared as main stock and 6 different concentrations were obtained by dilution. $3 \mathrm{~mL}$ samples were taken from each concentration $(50,75,100,150,200$, 300 ) and $1 \mathrm{~mL} 0.1 \mu \mathrm{M}$ DPPH was added on top. The reaction mixture was incubated for $30 \mathrm{~min}$ in the dark. BHT (butyl hydroxytoluene) and BHA (butyl hydroxyanisol) were used as reference. The DPPH was determined as the inhibition percentage and the following formula is used:

Radical scavenging activity DPPH \%= [A blank -A sample) $/$ A blank $]$ x100.

Spectrophotometric measurements for DPPH radical scavenging activity determination were performed with the aid of PerkinElmer Lambda 25 UV/VIS spectrophotometer device.

\subsubsection{Ferric reducing antioxidant power (FRAP) assay}

Ferric reducing antioxidant power assay (FRAP) was determined according to the method of Benzie \& Strain (1999). Leaf and flower samples $(4 \mathrm{~g})$ were extracted with water distilled $\left(40 \mathrm{~mL}\right.$ ) (temp.: from 80 to $105^{\circ} \mathrm{C}$ ) during 20 min (Fraction I). The crop residues were extracted with distilled water $(60 \mathrm{ml})$ (temperature from 100 to $130^{\circ} \mathrm{C}$ ) during $30 \mathrm{~min}$ (Fraction II). Both fractions were filtered when cooled to $25^{\circ} \mathrm{C}$ (Benzie and Strain, 1999). This analysis evaluated the change in absorbance at $620 \mathrm{~nm}$ for 
the production of FeII-tripyridyltriazine from oxidised FeIII. The reagent was prepared via mixing $300 \mathrm{mmol} / \mathrm{L}$ acetate buffer with $10 \mathrm{mmol} / \mathrm{L}$ 2,4,6-tripyridyl-s-triazine with $40 \mathrm{mmol} / \mathrm{L} \mathrm{HCl}$ and $20 \mathrm{mmol} / \mathrm{L}$ ferric chloride at low $\mathrm{pH}$. Trolox was used as standard. Samples were quantified by a spectrophotometer (PerkinElmer Lambda 25 UV/VIS).

\subsubsection{Trolox equivalent antioxidant capacity (TEAC) assay}

Trolox Equivalent Antioxidant Capacity (TEAC) assay is consisted in the reducing of the absorbance of the ABTS ${ }^{+\bullet}$ at $734 \mathrm{~nm}$ (Re et al., 1999). ABTS $\bullet+$ was prepared by reacting ABTS solution with potassium persulfate $(2.45$ $\mathrm{mM})$. The ABTS ${ }^{\bullet+}$ solution at $734 \mathrm{~nm}$ was diluted with phosphate buffer. After addition to the diluted ABTS $\bullet+$ Trolox standard, the mixture was incubated for 15 minutes. Next, inhibition in absorbance at $734 \mathrm{~nm}$ was evaluated. samples were examined with a PerkinElmer Lambda 25 UV/VIS spectrophotometer.

\subsubsection{Hydroxyl radical scavenging capacity assay}

This method was analyzed according to the method of Halliwell and Gutteridge (2007). Hydroxyl radical scavenging capacity was assessed by detecting the ability of sample (flower) extracts to reduce the generation of 2hydroxy terephthalate which is a strong fluorescent in a reaction between hydroxyl radical and terephthalic acid $\left(\mathrm{C}_{8} \mathrm{H}_{6} \mathrm{O}_{4}\right)$.

\subsubsection{Superoxide scavenging capacity assay}

This method was specified as the superoxide radical inhibition caused to be decrescent of nitro blue tetrazolium to formazan (McCord \& Fridovich, 1969).

\subsection{Statistical analysis}

All measurements were carried out in triplicates. The results were expressed as mean \pm SD and analyzed using MS-Excel software.

\section{Results}

Results of the proximate composition of the analyzed Achillea collina flower and leaf samples are presented in Table 1. According to the results, the moisture and cellulose content of $A$. collina leaf samples was higher than that obtained for the flower samples. However, the chlorophyll a, b and total carotenoids flower samples were higher than leaf samples. To the best of our knowledge, there were no data in the literature regarding the proximate composition of A. collina plant parts from different geographical regions.

Nemeth et al. (2008) reported that the essential oil yield ratio of $A$. collina varied between $0.07-1.77 \%$. According to other studies the yield varied between $0.73 \%$, $0.28-0.63 \%$, and $0.09-0.80 \%$ (Spinarová \& Petrikova, 2003; Konakchiev et al., 2006). The variations in the obtained results related to the essential oil yield could be due to the ecological and geographical factors in which the samples were obtained (Nemeth, 2005; Bozin et al., 2008).

Kindlovits et al. (2016) reported that the phenol content of A. collina ranged from 139 to $220 \mathrm{mg}$ GAE/100 $\mathrm{g}$. The results of the antioxidant activity of $A$. collina are presented in Table 2. IC $_{50}$ value, $\mu \mathrm{g} / \mathrm{mL}$ BHA (19.662 \pm 0.34$)$ and BHT $(13.818 \pm 0.50)$ were used as standards. The antioxidant capacity of leaf samples was higher than the flower samples (Table 2). According to other studies from the literature, the essential oils expressed stronger scavenging effects and $\mathrm{IC}_{50}$ value was found to be 0.62 $\mathrm{mg} / \mathrm{mL}$ for A. collina (Bozin et al., 2008). Georgieva et al. (2015) studied the antioxidant activity (DPPH, ABTS, FRAP and CUPRAC assays) of A. millefolium (leaves and stems) and reported that the highest free radical scavenging activity was observed against CUPRAC (55.08 \pm 0.85 to $148.99 \pm 1.94 \mu \mathrm{M} \mathrm{TE} / \mathrm{g} \mathrm{dw})$, followed by FRAP $(38.16 \pm 0.47$ to $132.71 \pm 1.86 \mu \mathrm{M}$ TE/g dw), DPPH $(24.15 \pm 0.15$ to $116.74 \pm 0.21 \mu \mathrm{M}$ TE/g dw) and ABTS $(18.59 \pm 0.22$ to $125.75 \pm 2.24 \mu \mathrm{M} \mathrm{TE} / \mathrm{g} \mathrm{dw})$. Their results revealed that $A$. millefolium may be used as an easily accessible source of natural antioxidants and also as a possible food supplement or in pharmaceutical industry (Ali et al., 2017)

Table 1. The proximate composition of Achillea collina samples

\begin{tabular}{lcc}
\hline Parameters & leaves & flowers \\
\hline Moisture, \% & $8.84 \pm 0.08$ & $8.32 \pm 0.07$ \\
Yield of essential oil, \% (v/w) & $*$ & $0.344 \pm 0.0$ \\
Protein, \% & $*$ & $10.57 \pm 0.09$ \\
Cellulose, \% & $20.04 \pm 1.00$ & $19.45 \pm 0.90$ \\
Ash, \% & $*$ & $8.37 \pm 0.08$ \\
Chlorophyll (a), $\mu \mathrm{g} / \mathrm{g} \mathrm{dw}$ & $32.25 \pm 1.06$ & $42.22 \pm 1.05$ \\
Chlorophyll (b), $\mu \mathrm{g} / \mathrm{g} \mathrm{dw}$ & $56.19 \pm 5.71$ & $221.35 \pm 2.80$ \\
Total carotenoids, $\mu \mathrm{g} / \mathrm{g} \mathrm{dw}$ & $2.80 \pm 1.96$ & $16.39 \pm 0.80$ \\
Total phenol, mg GAE /g & $171.66 \pm 0.47$ & $137.33 \pm 8.73$ \\
Total flavonoid, mg QE/g & $8.50 \pm 0.43$ & $7.39 \pm 0.32$ \\
\hline
\end{tabular}

* Insufficient sample quantity

Table 2. Antioxidant activity of Achillea collina

\begin{tabular}{lcc}
\hline Methods & leaves & flowers \\
\hline FRAP assay, $\mu \mathrm{mol} / \mathrm{L}$ & $710.17 \pm 35.19$ & $511.96 \pm 39.71$ \\
TEAC assay, $\mu \mathrm{mol} / \mathrm{L}$ & $232.26 \pm 31.08$ & $85.43 \pm 19.30$ \\
$\begin{array}{l}\text { DPPH assay }(\mathrm{IC} 50 \text { value), } \mu \mathrm{g} / \mathrm{mL} \\
\begin{array}{l}\text { Hydroxyl radical scavenging } \\
\text { capacity, mM EtOH/mL }\end{array}\end{array}$ & $62.32 \pm 1.53$ & $102.28 \pm 1.27$ \\
$\begin{array}{l}\text { Superoxide scavenging capacity, } \\
\text { unit SOD/mL }\end{array}$ & $*$ & $22.9 \pm 6.1$ \\
\hline
\end{tabular}

* Insufficient sample quantity

The chemical composition of the Achillea collina essential oil is shown in Table 3. According to the results, 66 constituents representing $98.35 \%$ of the total oil content were identified in A. collina essential oil. As 24 of the essential oil components were with concentrations above $1 \%$. The main compounds (over 3\%) were: 1,8-cineole $(21.60 \%)$, camphor $(6.58 \%), \beta$-linalool $(5.25 \%), \gamma$-terpinene $(4.65 \%), \quad \gamma$-terpineol $(4.36 \%), a$-pinene $(3.96 \%)$, epicyclocolorenone $(3.30 \%)$, epi-cyclocolorenone $(3.25 \%)$, and p-cymene $(3.03 \%)$.

Distribution of major groups of essential oil components are shown in Table 3. Oxygenated monoterpenes $(52.80 \%)$ are the dominant group in the oil, followed by (oxygenated sesquiterpenes (21.36\%), monoterpene hydrocarbons (15.86\%), sesquiterpene hydrocarbons $(4.73 \%)$, phenyl propanoids $(3.92 \%)$, and oxygenated aliphatics $(1.33 \%)$. 
Table 3. The chemical composition of the essential oil from the flowers of Achillea collina

\begin{tabular}{|c|c|c|c|c|}
\hline № & $\mathrm{RT}, \min$ & RI a & Compounds & $\begin{array}{c}\text { Content } \\
\left(\% \text { of } \mathrm{TIC}^{\mathrm{b}}\right)\end{array}$ \\
\hline 1 & 9.02 & 908 & Santolina triene & $0.39 \pm 0.0$ \\
\hline 2 & 9.85 & 923 & $a$-Thujene & $0.90 \pm 0.0$ \\
\hline 3 & 10.05 & 930 & a-Pinene & $3.96 \pm 0.03$ \\
\hline 4 & 10.57 & 944 & Camphene & $0.27 \pm 0.0$ \\
\hline 5 & 10.70 & 952 & Thuja-2,4(10)-diene & $0.36 \pm 0.0$ \\
\hline 6 & 11.34 & 970 & Sabinene & $1.40 \pm 0.01$ \\
\hline 7 & 11.50 & 976 & $\beta$-Pinene & $2.68 \pm 0.02$ \\
\hline 8 & 11.70 & 982 & $(3 E)$-Octen-2-ol & $0.12 \pm 0.0$ \\
\hline 9 & 11.90 & 988 & $\beta$-Myrcene & $0.30 \pm 0.0$ \\
\hline 10 & 12.13 & 997 & Yomogi alcohol & $0.45 \pm 0.0$ \\
\hline 11 & 12.79 & 1013 & $a$-Terpinene & $0.58 \pm 0.0$ \\
\hline 12 & 13.07 & 1018 & p-Cymene & $3.03 \pm 0.03$ \\
\hline 13 & 13.22 & 1024 & D-Limonene & $0.11 \pm 0.0$ \\
\hline 14 & 13.40 & 1027 & 1,8-cineole & $21.60 \pm 0.20$ \\
\hline 15 & 14.13 & 1052 & $\gamma$-Terpinene & $4.65 \pm 0.04$ \\
\hline 16 & 14.51 & 1066 & (Z)-Sabinene hydrate & $1.22 \pm 0.01$ \\
\hline 17 & 14.99 & 1077 & Tolualdehyde & $0.39 \pm 0.0$ \\
\hline 18 & 15.45 & 1095 & $\beta$-Linalool & $5.25 \pm 0.05$ \\
\hline 19 & 16.28 & 1110 & 6-Campholenol & $0.26 \pm 0.0$ \\
\hline 20 & 16.77 & 1136 & (Z)-Verbenol & $0.75 \pm 0.0$ \\
\hline 21 & 16.91 & 1141 & Camphor & $6.58 \pm 0.06$ \\
\hline 22 & 17.27 & 1156 & (Z)-Chrysanthenol & $1.23 \pm 0.01$ \\
\hline 23 & 17.36 & 1162 & (E)-Chrysanthenol & $2.74 \pm 0.02$ \\
\hline 24 & 17.65 & 1166 & Borneol & $1.29 \pm 0.01$ \\
\hline 25 & 17.93 & 1176 & 1-Terpinen-4-ol & $2.55 \pm 0.02$ \\
\hline 26 & 18.38 & 1197 & $\gamma$-Terpineol & $4.36 \pm 0.04$ \\
\hline 27 & 18.66 & 1203 & Verbenone & $0.11 \pm 0.0$ \\
\hline 28 & 19.36 & 1230 & Pulegone & $0.33 \pm 0.0$ \\
\hline 29 & 19.44 & 1235 & Chrysanthenyl acetate & $0.21 \pm 0.0$ \\
\hline 30 & 20.63 & 1283 & $(E)-a$-Necrodol acetate & $1.15 \pm 0.01$ \\
\hline 31 & 20.84 & 1287 & Lavandulyl acetate & $1.66 \pm 0.01$ \\
\hline 32 & 20.96 & 1290 & $p$-Cymen-7-ol & $0.44 \pm 0.0$ \\
\hline 33 & 22.72 & 1324 & Myrtenyl acetate & $0.19 \pm 0.0$ \\
\hline 34 & 23.63 & 1385 & $\beta$-Cubebene & $0.26 \pm 0.0$ \\
\hline 35 & 23.77 & 1390 & $\beta$-Elemene & $0.89 \pm 0.0$ \\
\hline 36 & 25.06 & 1441 & (Z)- $\beta$-Farnesene & $0.13 \pm 0.0$ \\
\hline 37 & 25.49 & 1454 & a-Caryophyllene & $0.24 \pm 0.0$ \\
\hline 38 & 25.60 & 1458 & allo-Aromadendrene & $0.32 \pm 0.0$ \\
\hline 39 & 25.94 & 1477 & $\beta$-Chamigrene & $0.27 \pm 0.0$ \\
\hline 40 & 25.97 & 1479 & $a$-Curcumene & $0.41 \pm 0.0$ \\
\hline 41 & 26.17 & 1482 & Germacrene D & $0.38 \pm 0.0$ \\
\hline 42 & 26.35 & 1488 & $\beta$-Selinene & $0.13 \pm 0.0$ \\
\hline 43 & 26.64 & 1509 & $\gamma$-Cadinene & $0.52 \pm 0.0$ \\
\hline 44 & 27.02 & 1523 & $\delta$-Cadinene & $0.63 \pm 0.0$ \\
\hline 45 & 27.34 & 1536 & $a$-Cadinene & $0.29 \pm 0.0$ \\
\hline 46 & 27.57 & 1545 & a-Calacorene & $0.18 \pm 0.0$ \\
\hline 47 & 27.88 & 1562 & $(E)$-Nerolidol & $0.56 \pm 0.0$ \\
\hline 48 & 28.25 & 1573 & Germacrene D-4-ol & $0.15 \pm 0.0$ \\
\hline
\end{tabular}

\begin{tabular}{llllc}
\hline № & RT, min & RI a & Compounds & $\begin{array}{c}\text { Content } \\
(\% \text { of TICb) }\end{array}$ \\
\hline 49 & 28.37 & 1577 & Spathulenol & $0.37 \pm 0.0$ \\
50 & 28.46 & 1579 & (E)-Sesquisabinene hydrate & $2.26 \pm 0.02$ \\
51 & 28.58 & 1581 & Caryophyllene oxide & $3.25 \pm 0.03$ \\
52 & 29.00 & 1594 & Viridiflorol & $0.64 \pm 0.0$ \\
53 & 29.12 & 1602 & Ledol & $0.58 \pm 0.0$ \\
54 & 29.29 & 1630 & r-Eudesmol & $0.66 \pm 0.0$ \\
55 & 29.38 & 1638 & epi-a-Muurolol & $0.48 \pm 0.0$ \\
56 & 29.53 & 1652 & $a$-Cadinol & $1.51 \pm 0.01$ \\
57 & 29.76 & 1665 & 14-hydroxy-(Z)-Caryophyllene & $0.60 \pm 0.0$ \\
58 & 29.84 & 1669 & 14-hydroxy-(E)-Caryophyllene & $0.85 \pm 0.0$ \\
59 & 29.93 & 1674 & (Z)-Nerolidyl acetate & $2.75 \pm 0.02$ \\
60 & 30.25 & 1683 & (2Z,6Z)-Farnesal & $1.28 \pm 0.01$ \\
61 & 30.29 & 1685 & Germacra-4(15),5,10(14)-trien-1-a-ol & $1.15 \pm 0.01$ \\
63 & 31.12 & 1757 & Cyclocolorenone & $0.43 \pm 0.0$ \\
64 & 32.62 & 1778 & epi-Cyclocolorenone & $3.30 \pm 0.03$ \\
65 & 34.17 & 1861 & (Z,Z)-Farnesyl acetone & $0.19 \pm 0.0$ \\
66 & 36.69 & 1957 & $n$-Hexadecanoic acid & $1.18 \pm 0.01$ \\
\hline Oxygenated aliphatics,\% & 1.33 \\
Monoterpene hydrocarbons,\% & 15.86 \\
Oxygenated & monoterpenes,\% & 52.80 \\
Sesquiterpene hydrocarbons,\% & 4.73 \\
Oxygenated sesquiterpenes,\% & 21.36 \\
Phenyl propanoids, \% & & 3.92 \\
\hline & & & & \\
\hline & &
\end{tabular}

$\mathrm{RI}^{\mathrm{a}}$ - retention index(Kovat's); $\mathrm{TIC}^{\mathrm{b}}$ - total ion current

Bozin et al. (2008) reported that monoterpene $(27.19 \%)$, sesquiterpene hydrocarbons (28.02\%), oxygenated monoterpenes $(20.83 \%)$, and proazulenes $(19.42 \%)$ were determined in Achillea collina essential oil. The main components in the essential oil were $\beta$-pinene $(22.52 \%)$, chamazulene $(19.42 \%)$ and E-caryophyllene $(14.92 \%)$. The flowering tops containing essential oil are the most active part of the plant, used mainly for the treatment of influenza, hemorrhage, dysmenorrhea, diarrhea and as a homeostatic agent (Benedek et al., 2008).

Macro and micro element contents have been reported to play important roles in plant growth and development, including cell wall formation, photosynthesis, and respiration. At the same time, these nutrients provide the cofactors needed by numerous enzymes of primary and secondary metabolism. Moreover, the limitation or absence of an element can cause changes in the plant biosynthetic capacity (Figueiredo et al., 2008). Total dry matter, the order of limiting nutrients was $\mathrm{K}>\mathrm{Ca}>\mathrm{P}>\mathrm{Mg}>\mathrm{Na}$ for macroelements and $\mathrm{Mn}>\mathrm{Cu}>\mathrm{Fe}>\mathrm{B}$ for micro-elements (Figs. 1-2). In addition, the order of heavy metals was $\mathrm{Sr}>\mathrm{Rb}>\mathrm{Ni}>\mathrm{Ba}>\mathrm{Co}>\mathrm{Zn}$ (Fig. 3).

There were data for the mineral content of Achillea millefolium in the literature and it contained the highest concentrations of $\mathrm{Cu}\left(\mathrm{O}^{\prime}\right.$ Dell \& Claassen, 2015). The level of Ca was reported as low that affected the growth of $A$. millefolium more than other elements. Alvarengaa et al. (2015) reported the macro and micromineral composition content in the following order $\mathrm{Zn}>\mathrm{Fe}>\mathrm{B}>\mathrm{Cu}>\mathrm{Mn}>\mathrm{Mo}$ (for micro-elements) and $\mathrm{Ca}=\mathrm{K}=\mathrm{N}>\mathrm{P}>\mathrm{S}>\mathrm{Mg}$ (for macro- 
elements), respectively.

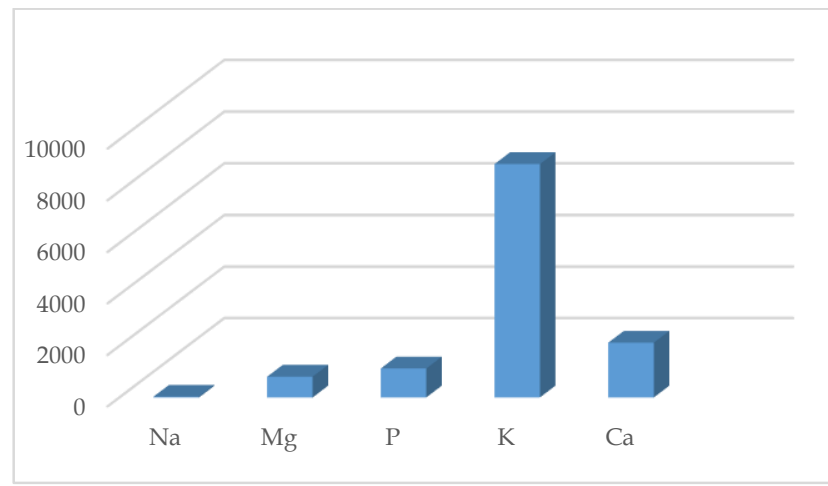

Figure 1. Macro-element content of the flowers of Achillea collina (ppm)

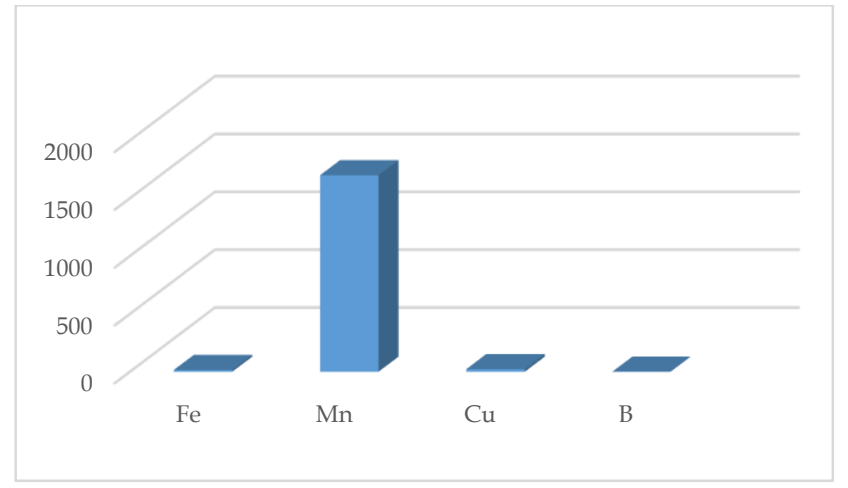

Figure 2. Micro-element content of the flowers of Achillea collina (ppm)

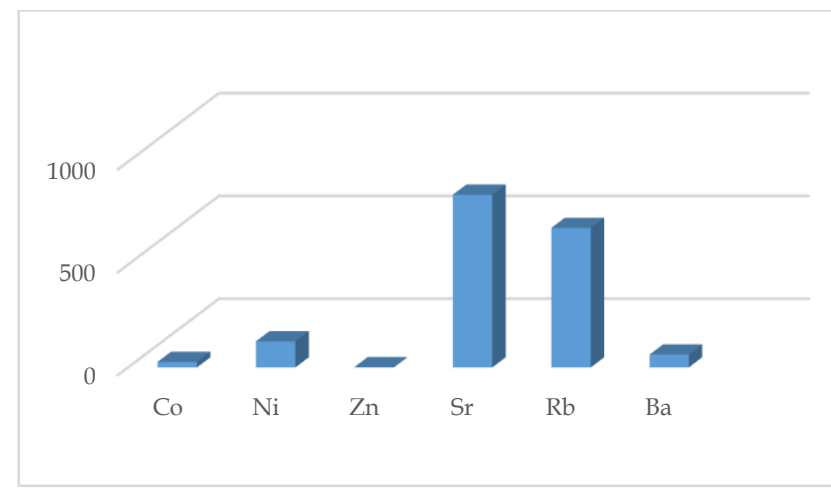

Figure 3. Heavy metals in the flowers of Achillea collina (ppm)

\section{Conclusion}

This study has shown that Achillea collina leaf samples obtained from Bulgarian flora has an higher antioxidant effect. Our study provided extensive evidence regarding the antioxidant activity and mineral composition of $A$. collina. The limiting mineral order for total dry matter was as follows $\mathrm{K}>\mathrm{Ca}>\mathrm{P}>\mathrm{Mg}>\mathrm{Na}$ (for macro elements) and $\mathrm{Mn}>\mathrm{Cu}>\mathrm{Fe}>\mathrm{B}$ (for micro elements). A. collina $\mathrm{EO}$ content was $0.3 \%$ and the most abundant chemical compound was 1,8-cineole $(21.60 \%)$, followed by camphor $(6.58 \%), \beta$ linalool (5.25\%) and $\gamma$-terpinene $(4.65 \%)$. The most active plant parts were Achillea collina leaves with a value of $\mathrm{IC}_{50}=62.32 \pm 1.53 \mu \mathrm{g} / \mathrm{mL}$. The highest total phenolic and flavonoid contents $(171.66 \pm 0.47 \mathrm{mg}$ GAE /g and $8.50 \pm 0.43 \mathrm{mg} Q E / g)$ were found in leaf parts.

In recent years, especially in Europe, Achillea collina subspecies was the most effective plant group in terms of utilization in pharmacy and food industry. The knowledge of herbal medicine together with the traditions and ecological resources of the regions as well as the effects of the biochemical and photochemical profile of plants could be a subject for further research.

Acknowledgements: This work is part of a project supported by the Yozgat Bozok University Scientific Research Projects Unit (BAP; Project Code: 6602a-TBMYO/20-356, Yozgat, Turkey).

Ethics committee approval: Ethics committee approval is not required for this study.

Conflict of interest: The author declares that there is no conflict of interest.

\section{References}

Adams, R.P. (2007). Identification of Essential Oil Components by Gas Chromatography/Mass Spectrometry (4th ed.). Allured Publishing Co., Carol Stream, Illinois, 804 pp.

Ali, S.I., Gopalakrishnan, B., \& Venkatesalu, V. (2017). Pharmacognosy, phytochemistry and pharmacological properties of Achillea millefolium L.: a review. Phytotherapy Research, 31, 1140-1161. http://doi.org/10.1002/ptr.5840

Alvarengaa, I.C.A., Boldrinb, P.F., Pachecoa, F.V., Silvaa, S.T., Bertolucci, S.K.V., \& Pintoa, J.E.B.P. (2015). Effects on growth, essential oil content and composition of the volatile fraction of Achillea millefolium L. cultivated in hydroponic systems deficient in macro- and microelements. Scientia Horticulture, 197, 329-338. https://doi.org/10.1016/j.scienta.2015.09.046

AOAC. (2005). Method 930.05. Ash of plants. Official Methods of Analysis (Horwitz, W. \& Latimer Jr., G.W., Eds.). Gaithersburg, MD, USA: AOAC International, $2200 \mathrm{pp}$.

AOAC. (2016). Method 976.06. Protein (crude) in animal feed and pet food. Official Methods of Analysis (Latimer Jr., G.W., Ed.). Geithersburg, MD, USA: AOAC International, $3172 \mathrm{pp}$.

Balinova, A., \& Diakov, G. (1974). On improved apparatus for microdistillation of rose flowers. Plant Science, 11, 77-85.

Benedek, B., Rothwangl, W.K., Rozema, E., Gjoncaj, N., Reznicek, G., Jurenitsch, J., Kopp, B., \& Glasl, S. (2008). Yarrow (Achillea millefolium); pharmaceutical quality of commercial samples. Pharmazie, 63, 23-26. https://doi.org/10.1691/ph.2008.7646

Benzie, F.F., \& Strain, J.J. (1999). Ferric reducing/ antioxidant power assay: direct measure of total antioxidant activity of biological fluids and modified version for simultaneous measurement of total antioxidant power and ascorbic acid concentration. Methods in Enzymology, 299, 1523. https: / doi.org/10.1016/S0076-6879(99)99005-5

Biju, J., Sulaiman, C.T., Satheesh, G., \& Reddy, V.R.K. (2014). Total phenolics and flavonoids in selected medicinal plants from Kerala. International Journal of Pharmacy and Pharmaceutical Sciences, 6, 406-408.

Brendel, O., Iannetta, P., \& Stewart, D. (2000). A rapid and simple method to isolate pure a-cellulose. Phytochemical Analysis, 11(1), 7-10. https://doi.org/10.1002/(SICI)1099-1565(200001/02)11:1\%3C7::AIDPCA488\%3E3.0.CO;2-U

Bocevska, B., \& Sovova, H. (2007). Supercritical $\mathrm{CO}_{2}$ extraction of essential oil from yarrow. Journal of Supercritical Fluids, 40, 360-367. https://doi.org/10.1016/j.supflu.2006.07.014

Bozin, B., Mimica-Dukic, N., Bogavac, M., Suvajdzic, L., Simin, N., Samojlik, I., \& Couladis, M. (2008). Chemical composition, antioxidant and antibacterial properties of Achillea collina Becker ex Heimerl s.l. and A. pannonica Scheele Essential oils. Molecules, 13(9), 2058-2068. https://doi.org/10.3390/molecules13092058

Chávez-Silva, F., Cerón-Romero, L., Arias-Durán, L., Navarrete-Vázquez, G., Almanza-Pérez, J., Román-Ramos, R., Ramírez-Ávila, G., PereaArango, I., Villalobos-Molina, R., \& Estrada-Soto, S. (2018). Antidiabetic effect of Achillea millefollium through multi-target interactions: aglucosidases inhibition, insulin sensitization and insulin se-cretagogue activities. Journal of Ethnopharmacology, 212, 1-7. http://doi.org/10.1016/i.jep.2017.10.005

Choudhary, M.I., Jalil, S., Todorova, M., Trendafilova, A., Mikhova, B., \& Duddeck, H. (2007). Inhibitory effect of lactone fractions and individual components from three species of the Achillea millefolium complex of Bulgarian origin on the human neutrophils respiratory burst activity. Natural Product Research, 21(11), 1032-1036. https://doi.org/10.1080/14786410701369623 
Corte Real, J., Bertucci, M., Soukoulis, C., Desmarchelier, C., Borel P Richling, E., ... \& Bohn, T. (2017). Negative effects of divalent mineral cations on the bioaccessibility of carotenoids from plant food matrices and related physical properties of gastro-intestinal fluids. Food $\mathcal{E}$ Function, 8, 1008-1019. https:/ / doi.org/10.1039/c6fo01708h

Dzhabarova, Y., \& Peneva, M. (2017). The value-added marketing - local products in conformity with vital rural areas, Trakia Journal of Sciences, 15 (1), 338-342. https:// doi.org/10.15547/tjs.2017.s.01.059

Edreva, A., Vitkova, A., Dagnon, S., Konakchiev, A., Gesheva, E., \& Bojilov, D. (2017). Field-cultivated medicinal plants of Achillea millefolium group: A source of bioactive compounds. Genetics and Plant Physiology, 7(1-2), 22-33.

Figueiredo, A., Barroso, J., Pedro, L., \& Scheffer, J. (2008). Factors affecting secondary metabolite production in plants: volatile components and essential oils. Flavour and Fragrance Journal, 23(4), 213-226. https://doi.org/10.1002/ffj.1875

Georgiev E., \& Stoyanova A. (2006). A Guide for the Specialist in the Aromatic Industry (1nd ed.). University of Food Technologies Academic Publishing House, Plovdiv, Bulgaria, 320 pp.

Georgieva, L., Gadjalova, A., Mihaylova, D., \& Pavlov, A. (2015). Achillea millefolium L. phytochemical profile and in vitro antioxidant activity. International Food Research Journal, 22(4), 1347-1352.

Gezer, K., Duru, M., Kıvrak, I., Türkoğlu, A., Mercan, N., Türkoğlu, H., \& Gülcan, S. (2006). Free-radical scavenging capacity and antimicrobial activity of wild edible mushroom of Turkey. African Journal of Biyotechnology, 5 (20), 1924-1928.

Halliwell, B., \& Gutteridge, J. (2007). Free radicals in biology and medicine (4th ed.). New York, Oxford University Press, 851 pp.

Kaçar, B., \& İnal A. (2010). Plant Analysis (2th ed.). Ankara, Turkey, Nobel Yayıncilık, 912 pp.

Kindlovits, S., Cserháti, B., Inotai, K., Rajhárt, P., \& Németh-Zámbori, E. (2016). FSL 1: Comparative investigation of 11 Achillea collina Becker accessions concerning phenological, morphological, productional features and active agent content. 6 th International Symposium Breeding Research on Medicinal and Aromatic Plants, June 19-23, 2016, Quedlinburg, Germany. https://doi.org/10.5073/jka.2016.453.025

Konakchiev, A., Todorova, M., Mikhova, B., Vitkova, A., Najdenski, H., \& Duddeck, H. (2006). Chemical composition and antimicrobial activity of the essential oil from two Achillea collina Becker. Comptes Rendus de I'Acedemie Bulgare Des Sciences, 59(5), 505-510.

Konemann, B. (1999). The Illustrated A-Z of over 10.000 Garden Plants and How to Cultivate Them, Gordon Cheers Publication, Hong Kong, 1020 pp.

Lakshmi, T., Geetha, R.V, Roy A., \& Aravind Kumar, S. (2011). Yarrow (Achillea millefolium linn.) a herbal medicinal plant with broad therapeutic use - a review. International Journal of Pharmaceutical Sciences Review and Research, 9(2), 136-141.

McCord, J., \& Fridovich, I. (1969). Superoxide dismutase: an enzymic function for erythrocuprein (hemocuprein). Journal of Biological Chemistry, 25(244), 6049-6055.

Mockute, D., \& Judzentiene A. (2010). Variability of the Essential Oils Composition of Achillea millefolium ssp. millefolium Growing Wild in Lithuania. Biochemical Systematics and Ecology, 31, 1033-1045. https://doi.org/10.1016/S0305-1978(03)00066-8

Nemeth, E. (2005). Essential oil composition of species in the genus Achillea. Journal of Essential Oil Research, 17(5), 501-512. https:// doi.org/10.1080/10412905.2005.9698978

Nemeth, E., Bernáth, J., \& Tarján, G. (2008). Quantitative and qualitative studies of essential oils of Hungarian Achillea populations. Journal of Herbs, Spices \& Medicinal Plants, 13(1), 57-69. https://doi.org/10.1300/J044v13n01_05

Oberprieler, C., Vogt, R., \& Watson, L. (2007). Tribe Anthe mideae Cass. 1819. The families and genera of vascular plants. In: Kadereit. JW \& Jeffrey C (ed) Berlin \& Heidelberg, Springer, 342-374.

O'Dell, R., \& Claassen, V. (2006). Serpentine and nonserpentine Achillea millefolium accessions differ in serpentine substrate tolerance and response to organic and inorganic amendments. Plant and Soil, 279, 253269. https:// doi.org/10.1007/s11104-005-2360-y

Re, R., Pellegrini, N., Proteggente, A., Pannala, A., Yang, M., \& Rice-Evans, C. (1999). Antioxidant activity applying an improved ABTS radical cation decolourisation assay. Free Radical Biology and Medicine Original Contributions, 26(9-10), 1231-1237. https://doi.org/10.1016/S08915849(98)00315-3

Rehus, L., \& Neugebauerova, J. (2011). The Comparison of the content of essential oil and favonoids in selected species of genus Achillea millefolium Agg. cultivated in conventional on orgnic way. Acta Fytotechnica et Zootechnica Special, Number, 33-35.

Singleton, V., Orthofer, R., \& Lamuela-Raventos, R. (1999). Analysis of total phenols and other oxidation substrates and antioxidants by means of Folin-Ciocalteu Reagent. Methods in Enzymology, 299(1999), 152-178. https://doi.org/10.1016/S0076-6879(99)99017-1

Somogyi, A., Rosta, K., Pusztai, P., Tulassay Z., \& Nagy, G. (2007). Antioxidant measurements. Physiological Measurement, 28(4), 41-55. https://iopscience.iop.org/article/10.1088/0967-3334/28/4/R01

Spinarová, S., \& Petříková, K. (2003). Variability of the content and quality of some active substances within Achillea millefolium complex. Horticulture Science (Prague), 30, 7- 13. https://doi.org/10.17221/3811HORTSCI

Stojanović, G., Radulović, N., Hashimoto, T., \& Palić, R. (2005). In vitro antimicrobial activity of extracts of four Achillea species: the composition of Achillea clavennae L. (Asteraceae) extract. Journal of Ethnopharmacology, 101(1-3), 185-190. https://doi.org/10.1016/i.jep.2005.04.026

Trendafilova A., Todorova, M., Mikhova, B., Vitkova, A., \& Duddeck H (2006). Sesquiterpene lactones from Achillea colina J. Becker ex Reichenb. $\begin{array}{lll}\text { Phytochemistry, } & 67(8), & \text { 764-770. }\end{array}$ https://doi.org/10.1016/j.phytochem.2006.01.033

Vitkova, A., Anchev, M., Goranova, V., Todorova, M., \& Konakchiev, A. (2005). Achillea millefolium group (Asteraceae) in Bulgaria. Farmacy (Bulgarian), 52, 60-63.

Yaeesh, S., Jamal, Q., Khan, A.U., \& Gilani, A.H. (2006). Studies on hepatoprotective, antispasmodic and calcium antagonist activities of the aqueous-methanol extract of Achillea millefolium. Phytotherapy Research, 20(7), 546-551. https://doi.org/10.1002/ptr.1897 